\title{
Het publieke karakter van de kerk
}

G Heitink'

(Vrije Universiteit en Universiteit van Pretoria)

\section{ABSTRACT}

The public character of the church

The subject of this article is the public character of the church. In the Netherlands one can make a distinction between three actual models. Each of them has had influence on the relationship between church and society in a particular time of history. The first model of $A$ Kuyper, has its roots in the Reformed Churches in the Netherlands (Gereformeerde Kerken) and was important in the first half of the 20th Century. The second model is rooted in the Reformed Church (Nederlandse Hervormde Kerk) of the Netherlands in the period after World War 2. The third model is the ecumenical model of the "church for others", related to the secularized society. In each of these models we can find building blocks for the fourth model, called "open church", which has to be developed in this time of rapid social changes. In this article, the author tries to develop a design for the fourth model. This article is written out of the context of Western Europe. I hope it also can be helpful in the context of South Africa.

\section{INLEIDING}

Door de differentiatie van de samenleving zijn het kerkelijk leven en het maatschappelijk leven uit elkaar gegroeid, zo kunnen we lezen in godsdienstsociologische studies (Dekker 2000:157 ev). Ik schrijf vanuit de Nederlandse samenleving, waarin zich vanaf het midden van de Negentiende Eeuw een scherpe scheiding voltrokken heeft tussen kerk en staat. Deze ontwikkeling ging gepaard met een verkerkelijking van het christendom. De kerk kwam steeds losser te staan van de overige terreinen van het leven en verloor aan maatschappelijke relevantie. Daardoor raakte zij in een isolement en kreeg een sterk naar binnen gericht karakter. Vervolgens kwam de vraag op of en - zo ja - hoe, de kerk weer iets van haar publieke karakter zou kunnen terugwinnen. Dit laatste niet om opnieuw een overheersende rol in de samenleving te spelen, maar om recht te doen aan de overtuiging dat het christelijk geloof niet alleen van betekenis is voor het persoonlijk leven maar ook voor de opbouw van een rechtvaardige samenleving, waarin iets zichtbaar kan worden van Gods bedoelingen met mens

\footnotetext{
${ }^{1}$ Prof dr Gerben Heitink is hoogleraar praktische theologie aan de Vrije Universiteit te Amsterdam en honorair professor aan de Universiteit van Pretoria.
} 
en wereld. Het Koninkrijk Gods wordt gekenmerkt door vrede en gerechtigheid. Daarom gaan vragen van oorlog en vrede, rijkdom en armoede, welzijn en solidariteit de kerk ter harte.

Daarmee worden vragen gesteld aan de ecclesiologie. Hoe kan de kerk niet alleen instituut zijn en gemeenschap maar ook een "brug gebeuren" (Berkhof 1973:430) naar de samenleving? Dit roept de vraag op welk kerkmodel van betekenis kan zijn voor de bevordering van het publieke christendom. In de Nederlandse situatie is in de loop van de twintigste eeuw vorm en inhoud gegeven aan verschillende kerkmodellen. In dit artikel beperk ik mij tot drie, die met het oog op de vraag naar het publieke karakter van de kerk nader onderzoek verdienen. Ik noem ze respectievelijk het gereformeerde model, het hervormde model en het oecumenische model. Drie andere, het theocratische model, het lutherse model van de twee rijken - leer en het evangelicale model, blijven hier buiten beschouwing. Mede aan de hand van deze drie modellen wil ik de volgende praktisch - theologische vraagstelling beantwoorden: Welk kerkmodel is in de huidige culturele situatie het meest geschikt om recht te doen aan de bevordering van het publieke karakter van het christelijk geloof? Mijn vooronderstelling hierbij is dat in elk van de drie modellen bouwstenen te vinden zijn die van betekenis zijn voor een model dat past bij de huidige culturele situatie.

Daarbij besef ik dat er verschillen bestaan tussen de culturele situatie in Nederland en in Zuid Afrika. Sleutelbegrippen in de analyse van de culturele situatie in West Europa zijn: modernisering en rationalisering, differentiatie en pluralisering, individualisering en secularisatie (vgl Steck 2000:26; \& Heitink 1993). Het zijn begrippen die ook in de Zuid-Afrikaanse context niet onbekend zijn. Vandaar mijn hoop dat deze bijdrage ook hier herkenbaar zal zijn.

\section{HET GEREFORMEERDE MODEL}

Met het gereformeerde model bedoel ik in dit verband het neo-calvinistische model van Abraham Kuyper, dat het gereformeerde denken en handelen op het gebied van kerk, staat en maatschappij in de eerste helft van de twintigste eeuw ingrijpend heeft beïnvloed. Nog altijd is zijn invloed in de Nederlandse samenleving merkbaar. Kuyper trekt consequenties uit de scheiding van kerk en staat. De kerk als volkskerk heeft naar zijn mening haar tijd gehad. Hij stelt zich in op het proces van modernisering dat zich in de samenleving voltrekt en kiest voor een vrije kerk van mondige christenen, die zelf verantwoordelijk zijn voor de vormgeving van het kerkelijk en maatschappelijk leven. Zijn model is bij uitstek emancipatoir, gericht op de verheffing van het Gereformeerde volksdeel dat onder zijn leiding een belangrijke sociale stijging zou doormaken (vgl Hendriks 1971). Hij riep een christelijk dagblad in het leven, richtte een politieke 
partij op en stichtte de Vrije Universiteit. Op deze wijze kwam heel de kerk in dienst te staan van het leven in de samenleving.

Kuypers denken over de kerk is in eerste instantie niet zozeer beïnvloed door Calvijn maar door de Poolse theoloog A Lasco, die leiding gaf aan de opbouw van de Nederlandse vluchtelingengemeenten in Londen en Emden. Diens visie op de kerk vormde het onderwerp van zijn promotiestudie. Voor A Lasco is het wezen van de kerk geestelijk. Hij ziet haar als een vrije broederlijke gemeenschap met een hoog democratisch gehalte. In zijn bekende Confidentie uit 1873 legt Kuyper sterk de nadruk op de zelfstandigheid van de plaatselijke kerk en de mondigheid van de gelovigen. Het ambt moet in het priesterschap der gemeente wortelen. Deze nadruk op de mens als gelovige mag niet leiden tot individualisme. De kerk als lichaam van Christus openbaart zich namelijk in gemeentelijke vorm (vgl Kuyper 1873: 43). Kuyper had behoefte aan een vaste kerk en, inmiddels gevoed door het denken van Calvijn, sprak hij met heimwee over "de kerk als een Moeder die van der jeugd af onze schreden leidt" (Kuyper 1873:43). Voor hem was de kerk vooral de voedingsbodem van de gelovigen met het oog op hun geestelijk leven. Aan een invloedrijk instituut had hij geen behoefte. Niet alleen het ambt was naar zijn mening ingesteld "om der zonde wil", ook de kerk zag hij slechts als een noodverband (Kuyper 1883:24) op weg naar Christus' koningschap over het hele leven.

Voor de relatie van kerk en samenleving, waar de vraagstelling van dit artikel zich op richt, is van belang het onderscheid dat Kuyper maakte tussen "kerk als instituut" en "kerk als organisme". "Uit het organisme wordt het instituut geboren, maar ook door het instituut wordt het organisme gevoed" (Kuyper 1870:18). Ik citeer hier uit Kuypers intredepreek in Amsterdam, naar aanleiding van Eph 2:17. Het thema komt het uitvoerigst aan de orde in zijn bekende werk De gemeene gratie (1902-1904). Nu blijkt het niet eenvoudig deze bekende Kuyperiaanse onderscheiding goed te interpreteren. In een recente gezamenlijke studie over Kuyper van de VUtheologen C Augustijn en J Vree (1998) wijzen beiden op dit punt verschillende wegen ${ }^{2}$. Ik probeer hier zo goed mogelijk tussen de door hen gewezen klippen door te zeilen.Voor Kuyper was de kerk als lichaam van Christus primair een organisme, de door Christus verloste mensheid. Christus leeft voort in het leven van de gelovigen. Dit organisme is de onzichtbare kerk, maar het heeft eveneens betekenis voor de zichtbare kerk, het instituut. Een uitwendige vorm is onmisbaar. De kerk is noch alleen een instituut, noch alleen een organisme. Beide komen samen in vrije zich

\footnotetext{
${ }^{2}$ Volgens Augustijn komen begrippen als gemene gratie, antithese, kerk als instituut en organisme in Kuypers vroege werk niet voor. De idee van kerk als organisme uit 1870 heeft dan ook niets te maken met zijn beschouwingen in Gemeene gratie (19021904:41). Vree ziet dit anders en trekt een continue lijn van 1870 naar 1902 (1998:86 ev).
} 
verenigende kerken. Het organisme is het wezen van de kerk, het instituut de vorm. De bron, het organisme, ontvangt zoveel stromen van kracht, dat de bedding, het instituut, die niet kan bevatten. De stroom treedt buiten haar oevers en bevrucht zo heel de samenleving (Augustijn \& Vree 1998:98). Het organisme is ook buiten het instituut aanwezig. Kuyper dacht aan een bescheiden instituut, dat in dienst stond van het organisme, het leven der individuele christenen. Het organisme, met als kern de wedergeboorte, staat verre boven het instituut. Het instituut is slechts instrumenteel. Zo staat heel de kerk in dienst van de kerstening van het persoonlijk en maatschappelijk leven. Daarom kende Kuyper in zijn Encyclopaedie een belangrijke plaats toe aan de laïcale vakken, waarin het gaat om de verantwoordelijkheid van de gelovigen, individueel en in organisatorisch verband.

Hierbij komt in De gemeene gratie het onderscheid tussen particuliere en algemene genade. Voor Kuyper beperkt het instituut zich tot hen die bewust uit de particuliere genade willen leven. Maar zo 'n kerk heeft uitstraling, zoals Kuyper met een bekend beeld duidelijk maakt:

"Al brandt de lamp der Christelijke religie alleen binnen de wanden van dat instituut, haar licht straalt door de vensters zeer verre daarbuiten uit, en werpt zich op al die geledingen en verbindingen van ons menschelijk leven... Recht, wet, gezin en familie, bedrijf, beroep, publieke opinie en letterkunde, kunst en wetenschap en zooveel meer, het wordt alles door dat licht bestraald... En het is door den zijdelingschen invloed, dat de kerk als instituut, heel het volk en heel het leven des volks zegent" (Kuyper 19021904:268 v).

De kerk als instituut bestaat uit hen die Gods naam willen belijden, de kerk als organisme is de invloed, die van de kerk als instituut op het volksleven uitgaat (Augustijn en Vree, 1998:44 v). Volgens Augustijn rept Kuyper in dit verband nauwelijks over christelijke organisaties. Zijn denken is dynamischer. Alle terreinen van het leven behoren tot het domein van de gemene gratie, waar door de kerk als organisme ook de particuliere genade in doorwerkt. Zo bereikt hij volgens Augustijn zijn doel, de verbinding van natuur en genade, van christelijk leven en leven in de wereld. Men mag deze visie niet belasten met het later door Kuyper geïntroduceerde begrip antithese, waarmee de christelijke groepering in de samenleving van de niet-christelijke wordt afgescheiden en dat ten dele politiek gekleurd is. Dat leidt tot een christelijk isolement, zoals de latere ontwikkeling van dit model helaas laat zien. Ook Kuypers brede visie viel ten prooi aan de verzuiling, die zo kenmerkend zou worden voor de Nederlandse samenleving tijdens de eerste helft van de vorige eeuw. 
Samenvattend kent het hier geschetste gereformeerde model slechts een bescheiden functie toe aan de kerk als instituut. Het priesterschap der gelovigen en niet de ambtelijke organisatie vormt het draagvlak van de kerk. Niet via het instituut oefent de kerk invloed uit op de samenleving, maar via het organisme. Het instituut is er tot voeding van het organisme, dat tot uitdrukking komt in het leven der gelovigen zowel binnen als buiten de kerk. Zij mogen in grote openheid in de samenleving staan, want op alle levensgebieden is de invloed merkbaar van Gods algemene genade, waardoor Hij deze wereld niet aan haar lot overlaat. De inwerking van de particuliere genade via mondige christenen op de samenleving, al dan niet in georganiseerd verband, is heilzaam voor mens en wereld. Het model heeft gaandeweg aan betekenis ingeboet. Door het voortgaande proces van differentiatie werd het steeds moeilijker de samenleving op te vatten als een organisch geheel. Door dit proces verloor de kerk haar invloed op grote delen van de samenleving. Christelijke organisaties en instellingen, bijvoorbeeld op het gebied van gezondheidszorg en welzijn, verloren hun identiteit en gingen voor een deel op in algemene verbanden. Ze werden geleid door professionals, die primair op hun vakkennis worden benoemd. Van meer betekenis is thans welke positie individuele christenen in de samenleving innemen. De belangrijkste invloed van de kerk heeft plaats via haar leden. De functie van het instituut blijft dan de toerusting tot christen zijn in deze wereld, onder meer via vormen van moreel beraad. Dat is nog altijd de actualiteit van het gereformeerde model. De godsdienstsocioloog G Dekker (2000:172) pleit daarom voor een indirecte benadering van de samenleving, namelijk via het leven van de leden dat zij in de samenleving leiden: "Ik denk nog steeds dat de meest voor de hand liggende en ook de meest effectieve manier om met de problemen van de samenleving bezig te zijn de weg via het leven van de leden is."

\section{HET HERVORMDE MODEL}

Het tweede model is het hervormde model van de Christus - belijdende volkskerk. Door de afscheiding van de Gereformeerde Kerken in de negentiende eeuw (1834/1886) had de Nederlandse Hervormde Kerk een gevoelige aderlating ondergaan. Het was de vraag of de kerk ooit dit verlies te boven zou komen. Des te verrassender was het nieuwe élan waarmee deze kerk uit de Tweede Wereldoorlog tevoorschijn kwam. Nog tijdens de oorlog verscheen een uitvoerige notitie van de werkgroep "Kerk en gemeenteopbouw" (De dienst der kerk ... 1945-1955:514-530), waarin de lijnen werden uitgezet voor een nieuw kerkelijk beleid. Hieraan was een periode van kerkvernieuwing voorafgegaan (vgl Bruin 1992), waaraan de namen van O Noordmans en $\mathrm{H}$ Kraemer verbonden waren. In de genoemde notitie wordt het begrip Christus - belijdende volkskerk toegelicht. Deze "slagzin" kan namelijk misverstanden wekken. Men waarschuwt voor romantiek. Het 
Nederlandse volk is niet langer "een gedoopte natie". Het begrip volkskerk slaat vooral op de verantwoordelijkheid die de kerk wil dragen voor heel het volk. Ook de overheid blijft binnen het vizier van de kerk: " $Z i j$ weet zich geroepen de geboden Gods voor te houden aan de overheden". Daarbij gaat het niet om macht, maar uitdrukkelijk om dienst. Bedacht moet worden dat de kerk ook in veel gevallen het evangelie in de weg staat. Daarom geldt: "Alleen een Kerk, die zelf, in de kennis van schuld en genade, uit de barmhartigheid van God leeft, kan de boodschap van Gods barmhartigheid uitdragen in woord en daad". Deze visie wordt kracht bijgezet door de zendingsman $\mathrm{H}$ Kraemer in zijn profetisch geschrift "De roeping der kerk" (1945).

Een concrete uitwerking van deze visie biedt de nieuwe Kerkorde van 1951. Deze heeft twee brandpunten: apostolaat en belijden (Dingemans 1987:19). Belijden en getuigenis horen bij elkaar. Na lange discussies over de Kerkorde werd besloten het artikel over het apostolaat der kerk te plaatsen vóór het artikel over het belijden der kerk. Bewust spreekt men van belijden en niet van belijdenis, om zo de actualiteit van het getuigenis te benadrukken. De aanhef van het artikel over het apostolaat luidt: "Als Christus - belijdende geloofsgemeenschap gesteld in de wereld om Gods beloften en geboden voor alle mensen en machten te betuigen, vervult de Kerk, in de verwachting van het Koninkrijk Gods haar apostolische opdracht..." (Art VIII). In dit artikel beluisteren we de echo van de theologie van A A van Ruler, die het denken over het apostolaat van de kerk sterk heeft beïnvloed (vgl Van Ruler 1948). De zending van de kerk in de wereld (de missio Dei) werd weer gezien als het hart van de kerk. Terwijl binnen de Gereformeerde Kerken de term apostolisch als regel verbonden werd met het fundament der kerk, zoals neergelegd in de geschriften van de apostelen, verbond de Hervormde Kerk dit, trouw aan de letterlijke betekenis van het werkwoord apostellein, met het uitgezonden worden in de wereld. Wat verder opvalt is het theocratische ideaal dat op verschillende plaatsen in de Kerkorde doorklinkt, als het getuigenis tegenover overheid en volk. De Hervormde Kerk heeft hier in de periode na de oorlog veel werk van gemaakt via kanselboodschappen en herderlijke schrijvens en door het oprichten van Raden, waarin de kerk, solidair en profetisch, in vragen en noden van de samenleving en op politiek terrein, zowel landelijk als mondiaal, haar stem verhief tegen wat naar haar mening niet met de wil van God overeenkwam. Het herderlijk schrijven tegen de kembewapening is hiervan een duidelijk voorbeeld:

"Op grond van wat wij over de vredestaak van de kerk en over de aard van de kernwapenen hebben gezegd, mag de kerk dan ook niet anders doen dan een radicaal neen tegen de kernwapenen uitspreken" (Het vraagstuk der kernwapenen... 1962:24). 
Voor Van Ruler is heel het leven van de kerk van het apostolaat doortrokken. Dat geldt van prediking, pastoraat, doop en avondmaal, catechese, huwelijk, theologische opleiding, eredienst en diaconaat. Alles heeft een missionaire spits, aldus H Noordegraaf (1998:106). Voor Van Ruler is heel de schepping, met een woord van Calvijn, "theatrum gloriae Dei". Heel zijn theologie is gericht op de eschatologie, de voltooiïng van de schepping in het Rijk Gods.

Een radicalisering van de apostolaatstheologie vinden we bij de bekende missioloog en oecumenicus J C Hoekendijk. De tijd van het Corpus Christianum is naar zijn overtuiging voorbij. Hij gelooft niet meer in een kerk die een apostolische functie heeft, maar draait dit om: "Ik geloof in de kerk, die een functie van het apostolaat is, dat wil zeggen een instrument van Gods verlossend handelen in deze wereld". De kerk is "een middel in Gods handen om sjaloom op te richten in deze wereld" (Hoekendijk 1964:24). De gangbare apostolaatstheologie is hem te parmantig. Ze hoort eerder bij een voorbije cultuur dan bij een post - christelijke samenleving. In deze samenleving moet de kerk overschakelen van "de derde mens", de kleinkinderen van de Verloren Zoon, naar "de vierde mens", door hem getypeerd als "post - christelijk, post - kerkelijk, post - burgerlijk en post - persoonlijk". "Deze vierde mens is onze weggenoot geworden" (Hoekendijk 1964:59). Het apostolaat beweegt zich in een kerkelijk niemandsland. De leken, gemeentelden, ziet hij als de dragers van de beweging die in hun leven iets van de solidariteit van Christus laten zien. Dit komt vooral tot uitdrukking in het diaconaat, door hem getypeerd als "stille pantomime van het heil".

Het apostolaat heeft heel de kerk in beweging gebracht en tot verrassende nieuwe initiatieven geleid. Ik noem de oprichting van het instituut "Kerk en Wereld" in 1945, als een centrum voor kerkelijk beraad en kadervorming en de WIKA-opleiding (Werker In Kerkelijke Arbeid), een opleiding voor een nieuw soort kerkelijke werker, naast de predikant, die beter kon inspelen op de differentiatie van de samenleving. $\mathrm{Zij}$ vonden een plaats in sociaal werk, recreatiewerk en in het industriepastoraat. Typerend voor de beweging was verder de doorbreking van de verzuiling. Veel christenen doorbraken het isolement waarin christelijke organisaties, voortgekomen uit het Réveil en de beweging rond A Kuyper, terechtgekomen waren. Zij kozen met overtuiging voor het socialisme en werden lid van de nieuw opgerichte Partij van de Arbeid. Onder hen waren bekende kerkelijke voormannen als ds J J Buskes, hiertoe mede gestimuleerd door de theologie van Karl Barth. Deze "doorbraak" werd kerkelijk gelegitimeerd in het herderlijk schrijven "Christen zijn in de Nederlandse samenleving" (1955). Ieder kerklid moet zelf kiezen of hij lid wordt van een christelijke dan wel een algemene organisatie. Christelijke organisaties krijgen onder andere deze waarschuwing mee: " $\mathrm{Zij}$ zullen zich er voor moeten hoeden in hun betrekkelijke afgeslotenheid te gaan staan tussen de Kerk en hun medemensen, 
opdat ze geen belemmering worden voor de doorwerking van het evangelie" (Documenten ... 1945-1955: 462).

Samenvattend kan gezegd worden dat dit model in de eerste decennia na 1945 zegenrijk heeft gewerkt. Deze tijd na de oorlog was voor Nederland een periode van wederopbouw. De vernieuwde kerk werkte aanstekelijk in op ontwikkelingen in de samenleving. Toch heeft Hoekendijk met zijn kritische opstelling in zekere zin een vooruitziende blik gehad. De brede visie op het apostolaat veronderstelt dat de kerk binnen de samenleving een belangrijke missie kan vervullen. Dat was steeds minder het geval. Het apostolaat werd ingehaald door de secularisatie. De kerk verloor steeds meer het contact met brede sectoren van de samenleving. Naar haar profetische woorden werd steeds minder geluisterd. De publieke boodschap verstomde. De politieke vertaling van het evangelie verloor na de roerige jaren zestig veel van haar krachtige aanhang. De oecumenische Basisbeweging, in de jaren zeventig ontstaan uit het initiatief van kritische jonge kerkleden, is thans vergrijsd. Ook zij die lid zijn van een kerk vertonen niet meer het engagement dat zo kenmerkend was voor de eerste decennia na de Tweede Wereldoorlog. Ook de kerkelijke gemeenschap is geïndividualiseerd. De kerkelijke raden, kwamen steeds meer in de greep van professionals en raakten verstard in een groeiende bureaucratie. De kerkelijke top raakte meer en meer vervreemd van het grondvlak. Het "Samen Op Weg" proces, tot hereniging van de Hervormde Kerk en de Gereformeerde Kerken, dat in de jaren zestig op gang kwam, riep aanvankelijk veel enthousiasme op, maar is in toenemende mate een bron van onderlinge conflicten en verdeeldheid geworden. De beweging is sterk binnenkerkelijk gericht en van het apostolaat is in de ontwerp - Kerkorde van de SOW-kerken nog maar weinig terug te vinden.

\section{HET OECUMENISCHE MODEL}

Het derde model dat ik schets ligt feitelijk in het verlengde van de geradicaliseerde apostolaatsvisie van J C Hoekendijk, die sterk betrokken was bij de theologische ontwikkelingen in de Wereldraad van Kerken. Ik noem dit het oecumenische model, het meest bekend onder de naam "Kerk voor anderen" (Church for others). De kerk is er niet voor zichzelf, maar voor anderen. $\mathrm{Zij}$ is er ten dienste van de oecumene, de hele bewoonde wereld. Dit vraagt dat de kerk zich ontledigt (kenosis, Phlp 2:7) en de dienstknechtsgestalte van haar Heer aanneemt (Zie voor een theologische oriëntatie: Schippers 1978). Het model is met name geïnspireerd op de gevangenschapsbrieven van D Bonhoeffer, aan wie ook de uitdrukking "er zijn voor anderen" ontleend wordt.

D Bonhoeffer schetst in zijn brieven, tastend en zoekend maar ook met profetische verve, de lijnen van een nieuwe wijze van gemeente - zijn 
in een radicaal geseculariseerde samenleving. Daarin lezen we onder andere deze woorden:

"De kerk moet meewerken aan de wereldlijke taken van het gemeenschapsleven, niet heersend maar helpend en dienend. Zij moct de mensen van alle beroepen voorhouden wat een leven met Christus is, wat het inhoudt 'te zijn voor anderen'..." (Bonhoeffer 1972:251. Ik maak hier verder gebruik van de analyse in: Heitink 1988).

De centrale vraag van Bonhoeffer is: Hoe kan Christus Heer worden ook van de a-religieuze mens? Hij wil trachten te begrijpen hoe de lijdende machteloze Christus het centrum van de wereld is. "Christus en de mondig geworden wereld", zo luidt de meest beknopte formulering van zijn thema. Volgens E Bethge (1968:895), zwager en erkend interpreet van Bonhoeffer, gaat het in de door hem geformuleerde vraag om drie samenhangende thema's: de "mondig geworden wereld", de "niet - religieuze interpretatie" van het evangelie en de "disciplina arcani".

Het eerste thema is mondigheid. In aansluiting bij Kant wil Bonhoeffer alle ruimte geven aan mondigheid en rationaliteit. De gekruisigde Christus maakt echte wereldlijkheid mogelijk. Onvoorstelbare uitspraken doet hij in dit verband: "God doet ons weten, dat wij moeten leven als mensen die met het leven klaarkomen zonder God", schrijft hij. "De God die met ons is, is de God die ons verlaat". Daarom meent hij: "De mondige wereld is godlozer en daardoor misschien dichter bij God dan de onmondige wereld". Zo geldt: "Voor en met God leven wij zonder God", en wordt ruimte gemaakt voor een ander godsbeeld: "de God van de Bijbel, die door zijn machteloosheid in de wereld macht en ruimte krijgt" (Bonhoeffer 1972:300 v). Het zijn woorden die ontspringen aan de aporie. Waar ons denken ophoudt, opent God een andere weg. Bethge (1968:911) benadrukt het volstrekt nieuwe van deze uitspraken:

"Men had de indruk de dingen tevoren nog nooit zo gehoord te hebben: dat het heer - zijn van Christus correspondeerde met wereldlijkheid, en navolging met participatie in het aardse; dat het naturlijke, het profane, het rationele, het humane zijn plaats kreeg niet tegen, maar met deze Christus".

Deze mondigheid vraagt een niet - religieuze interpretatie van het evangelie. Religie vertroebelt de blik op de tegenwoordige wereld en op Christus. Het spreken over God wordt erdoor beperkt tot een bepaalde provincie van het leven. Dan trekt religie zich terug in die uithoeken van de samenleving die nog niet door de menselijke geest zijn "verlicht". Religie leeft van de macht van God, maar de bijbel verwijst naar Gods onmacht en lijden. Religieus interpreteren van de werkelijkheid is slechts een poging de 
kerk als heilsinstituut te redden (Bonhoeffer 1972:285, 288). Het is moeilijk deze gedachten te operationaliseren. In de praktijk wordt de kern van het evangelie dan meestal geïnterpreteerd met behulp van het begrip bevrijding, op persoonlijk niveau aan de hand van de psychologie en psychotherapie en op maatschappelijk niveau als bevrijding uit verschillende vormen van onderdrukking, zoals door de politieke theologie en de bevrijdingstheologie gedaan wordt.

"Kerk voor anderen" wordt tenslotte ook verbonden met een ander woord van Bonhoeffer (1972:251) uit zijn bekende doopbrief: "Ons christen zijn zal in deze tijd bestaan uit slechts twee elementen: bidden en onder de mensen het goede doen". Hierin wordt het wereldlijk leven verbonden met het derde element, de disciplina arcani, de tucht van het zwijgen. Deze "Arkandisziplin" herinnert aan het leven van de eerste christenen. De viering van het heil vraagt in de nieuwe tijd een eigen ruimte. Discipline in gebed, viering en meditatie is namelijk meer dan ooit een levensnoodzaak voor hen die het geheim van Christus kennen. Zo wordt het geloof gevoed, maar dit laat zich moeilijk communiceren. Als grondwoorden van het christelijk geloof, zoals schepping, val, verzoening, laatste dingen, boete en opstanding niet meer met de mondige wereld in verband kunnen worden gebracht, dan past de kerk een zwijgen, net zo lang tot er opnieuw naar gevraagd wordt. Elke opdringerigheid en propaganda zijn vreemd aan de dienst van het evangelie (vgl Bethge, 1968:922-926). Het arcanum is geen schuilplaats, maar maakt deel uit van de ene wereld waarin christenen leven. Toch gaat het hier niet louter om een geïndividualiseerde geloofsbeleving. Bonhoeffer (1972:324 v) denkt hierbij wel degelijk aan de gemeente als een dragende gemeenschap.

"Vast staat, dat wij altijd in Gods nabijheid en tegenwoordigheid" mogen leven... Vast staat dat in het lijden onze vreugde, in het sterven ons leven verborgen ligt. Vast staat dat wij met dit alles staan in een gemeenschap die ons draagt. Op dit alles heeft God in Jezus Ja en Amen gezegd, (...) Had Jezus niet geleefd, dan was ons leven ... zinloos".

Bekend is dat ook $\mathrm{K}$ Barth de invloed van het denken van Bonhoeffer heeft ondergaan. Ik verwijs hier slechts naar passages uit zijn verzoeningsleer. Hierin kan hij hoog opgeven van de profane humaniteit die hierin tot uitdrukking komt dat een mens zich in zijn omgang met een medemens "schlicht mit ihm solidarisch findet und anspruchslos für ihn da ist" (Barth $1959^{1}: 140$ ). Deze solidariteit is zijn vertaling van "er zijn voor anderen". Barth merkt in dit verband op dat er ook extra muros ecclesiae ware woorden te vinden te zijn als gelijkenissen van het Hemelrijk. Elke bekeringskramp is hem vreemd want in onze door Christus verzoende 
wereld mag ieder mens gezien worden als christianus designatus, dat wil zeggen christianus in spe (Barth 19592:927).

Binnen de praktische theologie heeft met name Ernst Lange lijnen van Bonhoeffer doorgetrokken. Lange (1981:54) neemt van Bonhoeffer over "dass das Gebot der Stunde ein 'Minimum von Kirche' sei". Met deze woorden verwijst hij naar het "er zijn voor anderen", in de vorm van belangeloze presentie en dienst aan de samenleving. Lange heeft dit zelf in praktijk gebracht in het experiment van de "Ladenkirche" (Zie voor een evaluatie van dit experiment: Lange 1981:63-160). In een voormalige bakkerswinkel in het centrum van Berlijn vormde hij een gemeente als een laagdrempelige geloofsgemeenschap die zo goed mogelijk aansloot bij de behoeften van mensen die in deze buurt woonden. De opzet was mede gebaseerd op Amerikaanse voorbeelden, zoals de "East Harlem Protestant Parish" in Chicago. Dit resulteerde in een ander beeld van de gemeente (Lange 1981:177-194). Alles wat in de gemeente gedaan werd moest voortdurend beproefd worden op zijn relevantie voor het dagelijkse leven, zoals zich dat buiten de gemeente in de samenleving afspeelde. Leken speelden hierin een belangrijke rol en de diaconie werd gezien als grondmodel van de navolging van Jezus. De theologie mag niet langer denken in de volgorde "God - kerk - wereld", maar moet uitgaan van "God - wereld - kerk". De zending van God speelt zich af in de wereld, in ontmoeting met mensen. De gemeente is de plaats om de inspiratie op te doen om aan die zending deel te kunnen hebben.

Samenvattend gaat dit derde model uit van een radicaal geseculariseerde samenleving, waarin mensen buiten de kerk volstrekt vervreemd zijn van de christelijke traditie. Bijbelse grondwoorden zijn ontoereikend geworden om hier een brug te slaan. Ze spreken een andere taal dan die van de mondige mens. Zo wordt de kerk een randverschijnsel. Maar een kerk die zichzelf prijs durft geven (kenosis) om zo beter kerk van Jezus Christus te kunnen zijn, verliest wel aan macht, maar wint aan geloofwaardigheid. Zij leeft voort in vormen van christelijke gemeenschap rond Woord en sacrament, waar de gelovigen die het geheim van de navolging kennen samenkomen om geïnspireerd en bemoedigd te worden voor hun leven in een mondige wereld. Een "minimum aan kerk" als organisatie is nodig om in belangeloze dienst voor de samenleving beschikbaar te zijn in concrete diaconale projecten. Maar missionaire propaganda past niet meer. Pas waar mensen onder de indruk komen van die gezindheid van ontlediging en beschikbaarheid zullen zij vragen naar het geheim dat Christus voor de gelovigen belichaamt.

\section{MODEL "OPEN KERK"}

Alle drie besproken modellen worden gekenmerkt door contextualiteit in een concrete historische en culturele situatie. Op deze wijze probeert men 
vorm en inhoud te geven aan het publieke karakter van de christelijke godsdienst. Het gereformeerde model paste bij de Nederlandse samenleving in de eerste helft van de twintigste eeuw. Door de scheiding van Kerk en Staat, vastgelegd in de Grondwet van 1848, verloor de Nederlandse Hervormde Kerk haar bevoorrechte positie in de samenleving. Achtergestelde groeperingen, met name het gereformeerde en het katholieke volksdeel, maakten een versneld proces van emancipatie door dat gepaard ging met een grote opbloei van het kerkelijk leven. Door de politieke en maatschappelijke bewustwording in deze kringen kregen zij grote politieke en maatschappelijke invloed. De kerk als organisme bloeide, wat gepaard ging met een positieve visie op de zich ontwikkelende moderniteit via Kuypers opwaardering van de algemene genade.

Het hervormde model paste heel goed bij de periode van wederopbouw na de Tweede Wereldoorlog, toen alle groeperingen de handen ineen sloegen, wat gepaard ging met een sterk gevoel van saamhorigheid. Hierbij paste het niet dat christenen zich in eigen kring isoleerden ten opzichte van de samenleving. De antithese diende plaats te maken voor solidariteit. Naar de kerk werd geluisterd en zij kreeg weer een belangrijker stem op politiek en maatschappelijk gebied. Zo had zij invloed op het proces van dekolonisering en op het kernwapenvraagstuk. Daarbij ging zij soms opnieuw theocratische trekjes vertonen, wat gepaard ging met machtsaanspraken.

Door de snelle secularisatie vanaf de jaren zestig ontstond behoefte aan een nieuw model. Het oecumenische model "kerk voor anderen" kon hier de afgelopen decennia in voorzien. Het hielp de kerk zich bewust te worden van haar bescheiden rol in de samenleving. Een houding van pretentie maakte plaats voor een bescheiden vorm van presentie, belangeloze beschikbaarheid. Waar overheid en particulier initiatief gaten lieten vallen in de hulpverlening, zoals in de zorg voor drugsverslaafden en daken thuislozen, ontwikkelden de kerken belangrijke diaconale projecten om in deze behoefte te voorzien.

Maar ook dit model vertoont bepaalde tekorten, die in onze culturele situatie aanleiding vormen voor een proces van heroriëntatie. Ik noem er twee. Allereerst is Bonhoeffers voorspelling van de opkomst van de areligieuze mens maar ten dele uitgekomen. Binnen de huidige cultuur zijn nieuwe vormen van religie ontstaan, door de invloed van Oosterse religies en de opkomst van New Age. Deze bewegingen vormden een reactie op de rationalisering van de samenleving die heeft geleid tot een tekort aan emotionele betrokkenheid. Volgens onderzoek noemt ruim tweederde van de Nederlandse bevolking zichzelf religieus of zelfs gelovig, terwijl minder dan de helft van de bevolking een band heeft met een kerk. Er is met andere woorden veel geloof buiten de kerk. Het organisme is, om met Kuyper te spreken, ook buiten het instituut aanwezig. Uit hetzelfde onderzoek (Dekker 1997) blijkt dat in brede kringen van de bevolking verwachtingen leven ten aanzien van de kerk. Met name dat zij zich uitspreekt over 
politieke en maatschappelijke problemen. Men is niet meer bang voor een overheersende rol van de kerken, maar verwacht van haar een kritische tegenstem als bijdrage aan "de civiele samenleving". Ruim $65 \%$ van de bevolking ziet de kerken als een betrouwbare informatiebron. Hier liggen opnieuw aanknopingspunten voor een publieke rol van de kerken in de vorm van "civil religion".

Een tweede ontwikkeling is die in de richting van pluraliteit op het gebied van zingeving en levensbeschouwing. In een gerationaliseerde samenleving dreigt er een geestelijk vacuüm te ontstaan. Maar veel maatschappelijke vraagstukken vragen om mentaliteitsverandering, waarbij een beroep gedaan wordt op innerlijke motivatie, waarden en normen. In brede kring leeft een behoefte aan spiritualiteit, aan geestelijke bronnen van zingeving om uit te leven en te handelen. Veel mensen zijn op zoek naar zin en betekenis in hun bestaan, naar wat meer en hoger is dan zijzelf, noem het "God". Op de levensbeschouwelijke markt is het christendom een levensbeschouwing onder andere. Maar waar andere religies en levensbeschouwelijke stromingen, zoals het humanisme, met kracht voor hun overtuiging uitkomen, mogen ook christenen hieraan de vrijmoedigheid ontlenen om in alle openheid hun geloofstraditie te vertolken in woorden en daden. De kerk hoeft met andere woorden niet langer in haar schulp te kruipen en zich te verontschuldigen voor haar bestaan. De verontschuldigingscultuur voorbij komt er ruimte voor meer zelfbewustheid. Zo is de kerk bijvoorbeeld de belangrijkste leverancier op het gebied van vrijwilligerswerk, de kurk waar een groot deel van het gemeenschapsleven op drijft.

Dit vraagt in onze culturele situatie een nieuw model van kerk - zijn, dat ik wil omschrijven als het model "open kerk". Aan de drie genoemde modellen zijn hiervoor bouwstenen te ontlenen. Aan het gereformeerde model ontleen ik de nadruk op het priesterschap der gelovigen, dat zich niet binnen de kerk afspeelt maar daarbuiten. De invloed van het christelijk geloof in de samenleving is vooral afhankelijk van de inzet van individuele gelovigen, die op hun plaats in de samenleving met ieders eigen professionele expertise maatschappelijke vraagstukken helpen doordenken vanuit het evangelie en zo een bijdrage leveren aan de vernieuwing van de samenleving. Ook buiten de kerk is de invloed van Gods algemene genade werkzaam. In Kuypers termen gaat het hier om de kerk als organisme. Het is de taak van het instituut de gelovigen hiervoor toe te rusten. Zij moeten in de kerk een voedingsbodem vinden waaraan zij inzicht en inspiratie kunnen ontlenen. Daarmee wordt een sterke nadruk gelegd op de gemeente als leergemeenschap (vgl Schippers 1997). Het gaat hier om vormen van wederkerig leren tussen ambtsdragers en gemeenteleden, tussen ouderen en jongeren, tussen theologen en vertegenwoordigers van ander professies. Van de kerk wordt gevraagd zelf een lerende organisatie te zijn, open voor vernieuwing op basis van gedeelde ervaring. 
Aan het hervormde model ontleen ik opnieuw de vrijmoedigheid voor een bescheiden vorm van christelijk spreken ten aanzien van de noden en de vragen van de samenleving. Daarin kan het niet meer gaan om ambtelijke boodschappen, maar om een bijdrage aan het moreel beraad in de samenleving en een oriëntatie op vraagstukken waarin de humaniteit en de kwaliteit van het menselijk leven op het spel komen te staan. Ik denk hier op microniveau bijvoorbeeld aan het vraagstuk van de euthanasie, op mesoniveau aan de gevolgen van de vierentwintig - uurs economie en op macroniveau aan het milieuvraagstuk. Op deze wijze komt tot uitdrukking dat de kerk zich gezonden weet in de wereld. Deze wereld is geen vijandig gebied, zij is de in Christus verzoende wereld (Barth). Mensen mogen niet aangesproken worden op hun tekort, maar delen in de belofte van hun tegoed: schepsel Gods te zijn op aarde.

Aan het oecumenische model ontleen ik de erkenning van de mondigheid van de moderne mens, die overeen komt met wereldlijkheid en participatie in het aardse, in het vertrouwen dat God ons mensen hierin nabij is. Deze wereld valt niet uit Gods hand. Christus is Heer, ook van een mondige geseculariseerde wereld. In een "minimum van kerk" zal vooral aandacht dienen te zijn voor het doorgeven van het geheimenis dat we in Jezus Christus hebben leren kennen. Dat vraagt een openheid voor spiritualiteit. De bijdrage van de kerk dient, in navolging van haar Heer gezocht te worden in belangeloze presentie, het er zijn voor anderen. Dit laatste trouw aan het woord van Bonhoeffer: "De kerk moet loskomen uit haar verstarring. We moeten weer buitenlucht ademen, dialogeren met de wereld. We moeten het riskeren aanvechtbare dingen te zeggen, als daardoor de vitale vragen maar weer aan de orde komen" (Bonhoeffer 1972:313).

Het model "open kerk" wordt dus gekenmerkt door een dubbelstrategie. De eerste strategie is de gerichtheid op de leden van de gemeente om hen toe te rusten tot een mondig en doorleefd geloof en tot dienst aan de samenleving. Zij vormen "kemen" van gelovigen die het als hun voornaamste roeping zien het heil vóór te leven in de samenleving. De tweede strategie is de gerichtheid van de kerk op de samenleving, de vragen en noden van mensen. Hierbij kan gedacht worden aan de plaatselijke gemeente en aan de landelijke kerk. Wat de landelijke kerk betreft denk ik, zoals gezegd, allereerst aan vormen van moreel beraad, een oriëntatie op vraagstukken waar de humaniteit op het spel staat.

Van groot belang lijkt me een heroriëntatie op de lokale kerk. Door de ontwikkeling van gemeenteopbouw is de laatste decennia de gemeenschapsfunctie van de gemeente sterk benadrukt. Dit ging vaak gepaard naar een sterke gerichtheid naar binnen, een vorm van kerkelijke introvertie. Het model "open kerk" vraagt een "van buiten naar binnen denken". Een denken vanuit de behoeften van de mensen, met name de velen die leven in een kerkelijk niemandsland tussen geloof en ongeloof. De context van de lokale gemeente is in een dorp anders dan in een stad, in de ene streek van 
het land is zij anders dan in de andere. Daarom zal de invulling van het model plaatselijk verschillen. In alle gevallen gaat het echter om een leren denken vanuit de behoeften van mensen. Ik denk hier allereerst aan de behoefte ergens bij te horen (belonging), te horen bij een gemeenschap waar mensen naar elkaar omzien. Ik denk hierbij aan laagdrempelige samenkomsten, waar mensen met anderen in gesprek kunnen gaan, zoals een levensbeschouwelijk café. Ik denk vervolgens aan een behoefte tot zingeving. Daarbij gaat het om elementaire menselijke vragen: Waar leef ik voor? Wat geeft mij moed? Waaraan ontleen ik mijn inspiratie? Pastorale zorg mag zich niet beperken tot mensen binnen de kerk. Een derde behoefte is die aan informatie. Velen zijn van de christelijke traditie vervreemd en hebben nauwelijks meer enig idee van de levensvragen waarop het geloof antwoord geeft. De grondwoorden van de traditie zijn gestold tot dogma's. Duidelijk moet worden dat zij berusten op de ervaring van mensen met God, in een concrete situatie. Daarom denk ik aan een cursusaanbod waarin de elementaire vragen van de christelijke godsdienst aan de orde komen, in een open discussie. Ik denk tenslotte aan de behoefte tot ritualisering bij bepaalde overgangssituaties in het leven, bij geboorte, de verbondssluiting bij het aangaan van een relatie, bij overlijden. De kerk leeft van verhalen en rituelen en kan mensen helpen in de grenssituaties van hun leven momenten van overgang te markeren en daaraan zin te geven.

Kernwoord van dit model is gastvrijheid (vgl bijvoorbeeld: Stoppels 1996; Hendriks 1999). Het verwijst naar de bijbelse gastvriendschap. Letterlijk betekent het liefde tot vreemdelingen (philoxenia), Heb 13,2. Met verwijzing naar het verhaal van Abraham (Gn 18) kunnen die vreemdelingen wel eens engelen blijken te zijn. Sterker nog, in de vreemdeling kan met de Heer zelf ontmoeten (Mt 25). Het laatste hoofdstuk staat in een diaconale context, het weldoen aan de minste der broeders. Waar men probeert hieraan vorm te geven, ontdekt men hoe hoog de drempels zijn. De vreemdeling verstaat de taal niet die in de kerk gesproken wordt. De daar bekende omgangvormen zijn hem onbekend. Vaak voelen mensen zich object van zorg of van missionaire propaganda, in plaats van subject in een ontmoeting waarin het werkelijk om hen zelf gaat. Wederkerigheid in geven en ontvangen is wezenlijk voor een gastvrije gemeenschap. Gezocht moet worden naar laagdrempelige activiteiten, waarin mensen ontdekken echt welkom te zijn. Dat vraagt een evenmenselijke omgang, waarin niet de gemeenteleden zich als gastheer of gastvrouw boven de gasten verheffen maar ook zelf beseffen gast te zijn, want de enige gastheer is Jezus zelf. Zo 'n gemeente is een licht op een kandelaar en een schuilplaats in de wildernis, een haven in de storm van het leven, een plaats van opvang en bemoediging. Zo 'n model lijkt te passen bij een geïndividualiseerde samenleving, waarin mensen zich niet zozeer als leden aan cen organisatie binden maar wel op zoek zijn naar een plek, waar ervaringen gedeeld, aandacht geboden en liefde ontvangen wordt. Een plek om werkelijk op Verhaal te komen. 


\section{Literatuurverwysings}

a.s. De dienst der kerk in en aan het volk in het heden, in: Documenten Nederlandse Hervormde Kerk 1945 - 1955. 's Gravenhage: Boekencentrum.

a.s. Documenten Nederlandse Hervormde Kerk 1945 - 1955. 's Gravenhage: Boekencentrum.

a.s. 1962. Het vraagstuk der kernwapenen.... 's Gravenhage.

Augustijn. C \& Vree J, 1998, Abraham Kuyper: vaste en veranderlijk. Die ontwikkeling van zijn denken. Zoetermeer: Meinema.

Barth, K 1959. Die Kirchliche Dogmatik IV/3, I. Zürich.

- 1959, Die Kirchliche Dogmatik IV/3,2. Zürich.

Berkhof, H 1973. Christelijk geloof. Een inleiding in de geloofsleer. Nijkerk.

Bethge, E 1968. Dietrich Bonhoeffer. Theoloog - christen - tijdgenoot, 894-934 (895). Baarn.

Bonhoeffer, D 1972. Verzet en overgave. Nieuwe editie, 251. Baam.

Bruin, J 1992. Kerkvernieuwing. Een praktisch - ecclesiologisch onderzoek naar de betekenis van 'Gemeenteopbouw' voor de Nederlandse Hervormde Kerk. Zoetermeer: Boekencentrum.

Dekker, G e a, 1997. God in Nederland 1966-1996. Amsterdam.

Dekker, G 2000. Zodat de wereld verandert. Over de toekomst van de kerk. Baarn.

Dingemans, G 1987. Een huis om in te wonen. Schetsen en bouwstenen voor een Kerk en een Kerkorde van de toekomst. 's Gravenhage.

Heitink, G 1988. Om raad verlegen, doch niet radeloos... Ervaringen van aporie bij de beoefening der praktische theologie. Kampen (Kok).

- 1993, Praktische theologie: geschiedenis, theorie, handelingsvelden. Kampen: Kok.

Hendriks, J 1971. De emancipatie van de gereformeerden. Alphen aan den Rijn.

- 1999, Gemeente als herberg. De kerk van 2000 - een concrete utopie. Kampen: Kok.

Hockendijk, J C 1964. De kerk binnenste buiten, 24. Amsterdam (ten Have).

Kraemer, H 1945. De roeping der kerk. Ten aanzien van de wereld en van het Nederlandsche volk. 's Gravenhage.

Kuyper, A 1870. "Geworteld en gegrond". De kerk als organisme en instituut. Amsterdam.

- 1873. Confidentie, schrijven aan den weled. Heer J H van der Linden. Amsterdam.

- 1883. Traciaat van de Reformatie der Kerken, Amsterdam.

- De gemeene gratie (1902-1904). 3 dln, Amsterdam/Pretoria.

Lange, E 1981. Kirche für die Welt. Aufsätze zur Theorie kirchlichen Handelns. München.

Noordegraaf, H 1998. Vijf broden en twee vissen. Missionair gemeentezijn in een (post)moderne samenleving. Zoetermeer: Boekencentrum.

Schippers, K A 1978. "Kerk voor anderen" als model, in: H H Grosheide e a (red), De knechtsgestalte van Christus. Studies aangeboden aan prof $d r N H$ Ridderbos, 213223. Kampen: Kok.

- 1997. De gemeente als leergemeenschap. Kampen: Kok. 
Steck, W 2000. Praktische Theologie. Horizonte der Religion. Konturen des neuzeitlichen Christentums, Strukturen der religiösen Lebenswelt. Stuttgart: Kohlhammer.

Stoppels,. S 1996. Gastvrijheid. Het inloopcentrum als vorm van kerkelijke presentie. Kampen: Kok.

Van Ruler, A A 1948. Het apostolaat der kerk in de ontwerp-kerkorde. Nijkerk. 